\title{
Finding the Mother Tree: Discovering the Wisdom of the Forest
}

Suzanne Simard. 2021. ISBN 978-07352-237759. Penguin Canada. CAD \$ $34.95+$ shipping. Contact: www.penguinrandomhouse.ca

$\mathbf{T}$ he recent publication of the book, Finding the Mother Tree: Discovering the Wisdom of the Forest by Suzanne Simard ${ }^{1}$ is remarkable on two counts first, the author is a Canadian woman forester; second the book has been accorded major prominence by The New York Times, The Toronto Globe \& Mail and Scientific American. The book is primarily autobiographical and not a formal scientific presentation, although a major portion of Simard's scientific studies described in the book deal with the nature of the association of soil fungi and tree roots-mycorrhizal roots. The study of mycorrhizas is not new but Simard gives it an anthropomorphic twist, where in the introduction she tells the reader, "I was tapping into the messages that the trees were relaying back and forth through a cryptic underground fungal network". The messages are based on chemical signals which she states are "identical to our own neurotransmitters". Here are two statements for which to look for evidence in the book.

It seems worthy, therefore, of a brief historical account of the scientific studies of mycorrhizas that led to her own work since it is an arcane subject for the general reader and one of interest to foresters since Simard states that as a forestry undergraduate she learned next to nothing about mycorrhizas.

The term "mycorrhiza" was first used by a German botanist, A. B. Frank in 1885 to describe roots of trees associated with fungal hyphae, and Rayner in a classic account provides a history of the studies of plant root-fungal associations to $1927^{2}$. The first observations of

\footnotetext{
${ }^{1}$ Simard, Suzanne 2021. Finding the Mother Tree - Discovering the Wisdom of the Forest. Allan Lane. 348 p.

${ }^{2}$ Rayner M.C. 1927. MYCORRHIZA - an account of non-pathogenic infection by fungi in vascular plants and bryophytes. New Phytologist reprint No. 15. Wheldon \& Wesley, London. 246 p.
}

fungi in roots were in alder (1820), then later in the 1840s, in iris and orchids, culminating in 1857 with a full and accurate description of the association between root cells and fungus mycelia which we now call mycorrhiza. By this time they were noted to be present in many plant species, and when by the late 1870 s the basic nature of lichens as a combination of fungi with algae was known, the term symbiosis was coined by the German botanist de Bary in 1879 to describe the relationship between the two. The work of Frank culminating in 1885 was done for the German forestry department in Prussia interested in the propagation of truffles in their forests and of particular note was his opinion that the fungus associated with the tree roots was not parasitic but beneficial in providing water and mineral salts, i.e., nutrients to the tree from the soil. This symbiotic view was in direct contrast to the prevailing one that the fungus was parasitic to the tree.

The second period of studies during the early 1900s was marked by investigations of the physical nature of mycorrhizas and the distinction between roots where the hyphae penetrate into the root cells; the terms endotrophic and arbuscular were coined, based on the form of the fungal hyphae within the host root cells or where they formed a hyphal mass around the root, ectotrophic. As might be expected, some roots can exhibit both forms and were termed ectendotrophic. The mycorrhizal features associated with orchids received much attention, in part because of the interest of commercial growers of these plants, particularly the studies by the French botanist, Noël Bernard. Rayner noted the observation in 1911 by the Japanese researcher Kusano that the fungus associated with the orchid Gastrodia elata which occurs in oak woods, causes the tuber of the orchid to form flowers and fruit but does this by the transfer of food materi-

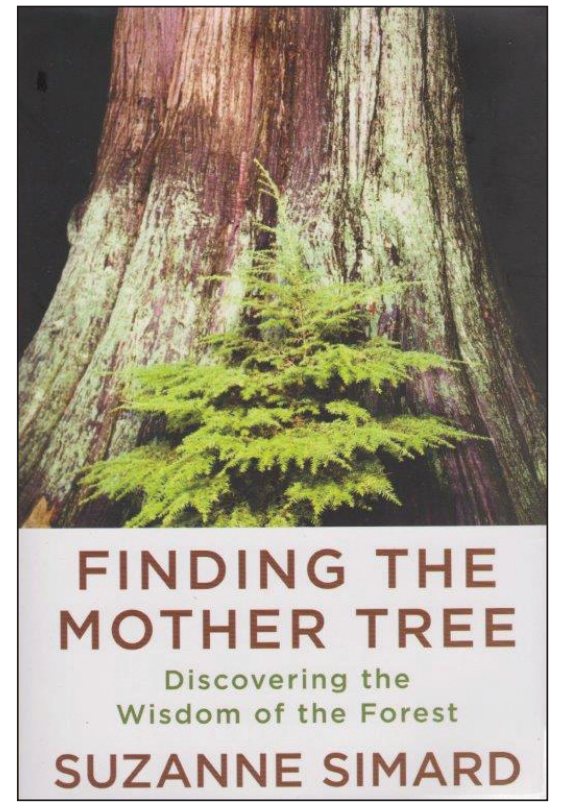

als from oak roots to which the fungus is attached. This must be one of the first suggestions of a mycorrhizal fungus mycelium acting as a transfer agent between two very different plant species. Rayner and other investigators carried out many studies of mycorrhizal occurrences on ericaceous species and determined that in Calluna (heather), the hyphae are extensive throughout the plant-roots, stem, leaves, flower and even the seed coats.

The nature of mycorrhizas on tree roots has been an area of many studies, in part because of some failures in the afforestation of heathland soils, for example, in Jutland where plantations of spruce suffered severe growth check or death. It was found that planting mountain pine (Pinus montana) as a nurse tree enabled the spruce to grow. It was conjectured that the mycorrhizas associated with the pines were similar to those of the heather and other heath plants and that the mycorrhizal fungi of the pine provided necessary nutrients to the spruce from the heather plants an observational record of a possible 
three-way connection between two conifer species and another nutrientproviding plant species. During this same period, mycologists were also busy identifying the various fungal organisms associated with the mycorrhizal roots of a range of tree species. At this time there were still conflicting views as to whether or not the fungus was parasitic, beneficial or neutral to the plant host and to what degree the structural nature, ectotrophic or endotrophic, signaled the nature of the relationship. In the 1920s and extending into the early 1950s, studies by the Swedish forest botanist Elias Melin contributed much to our knowledge of mycorrhizal symbiosis in several northern tree species, culminating in 1954 in his proof of the movement of photosynthates from a host tree to the fungus and of the nutrients nitrogen and phosphorus to the host tree from the fungus.

Harley and $\mathrm{Smith}^{3}$ give a comprehensive account of the nature of the structure, metabolism and nutrient uptake by mycorrhizas in various plants and their ecological significance. Much of the value of their work is the description of the physiological processes of mycorrhizal fungi. The transfer of carbohydrates from the host plant to the fungus and the movement of nutrients, particularly nitrogen and phosphorus, from the mycorrhizal fungus to the host plant has been well-documented since the early 1950s when radioisotopes of $\mathrm{C}, \mathrm{N}$ and $\mathrm{P}$ became available. Also, the fact that a mycorrhizal fungus can be connected to two different plant species, often quite different, such as between a conifer and heather ( $\mathrm{Cal}$ luna) offers insight into the nature of symbiotic relationships ecologically. The early notion that mycorrhizal fungi could be parasitic on the host has largely been replaced by evidence that it is a symbiotic relationship, the nature of the symbiosis can vary and in some instances the fungus may provide a protection to the host against a disease. In the 1970 s, Marx ${ }^{4}$ noted the function of

\footnotetext{
${ }^{3}$ Harley, J. L. and S.E. Smith. 1983. Mycorrhizal Symbiosis. Academic Press, London \& New York, 483 p.

${ }^{4}$ Marx, D. H. 1975. Role of ectomycorrhizae in the protection of pine from root infection by Phytophthora cinnamomi. In: "Biology and control of soil-borne plant pathogens". Ed J. W. Bruehl. American Phytopathological Society.
}

the mycorrhizal fungus providing protection to its pine host against the pathogen Phytophthora cinnamomi.

Now, we have in Simard's book the claim that there can be a recognition by a host plant of its offspring, i.e., a tree and its seedling regeneration, and that in some way the mycorrhizal fungus can act as a sensory mechanism between the two plants and transmit information about carbohydrate or nutrient needs from one to the other. This notion of fungal mycelia having sensory, directional and communicative capabilities independently and not necessarily as mycorrhizal symbionts has most recently been expounded by Sheldrake ${ }^{5}$.

Thus the history of studies of mycorrhizas shows the progression from initial recognition to anatomical identification, to evidence of host plant and fungus symbiotic dependence for carbohydrates and nutrients, to the ecological and now sensory and communicative functions. In this historical development, the scientific studies have relied on increasingly new and sophisticated devices and materials such as radioactive isotopes, yet it is the keen observations by individual scientists and their subsequent conjectures that have advanced our knowledge. The study of mycorrhizas has proceeded in bouts of interest for more than a century and a half and as Harley and Smith put it, referring to the spate of studies on nutrient uptake, "Then, as often happens, a fashion was set”. Will Simard's signal a new fashion in studies?

Her great-grand parents of Québécois origin settled in the Monashee mountain range of south central British Columbia. The family was involved with logging and moving logs on lakes to local sawmills and, in recounting family incidents or her own observations working in the forests, she often blends the two together. For example, in recounting how her uncles dug a hole adjacent to the outhouse to rescue the family beagle which had fallen into it, she describes the layers of soil so well that the profile is clearly identifiable as a podzol, typical on well-drained soils under conifer forests. Again, in her

\footnotetext{
${ }^{5}$ Sheldrake, Merlin 2020. Entangled Life: How fungi make our worlds, change our minds and shape our futures. Bodley Head, London
}

description of her early job working for a logging company checking planted seedlings on a cutover, she describes the mushrooms and how their interwoven mycelia in the forest floor give rise to recollections of her family and their relationships. Simard is the middle one of three siblings with a two-year older sister, Robyn and a two-year younger brother, Kelly, who is a farrier and a regular cowboy participant in local rodeos.

In recounting her bicycle ride to watch Kelly compete in a rodeo as a bull rider, she describes how she stops to walk through a woodland of ponderosa pines and Douglas-firs and ponders in the parched forest how the young seedlings and sapling trees, which seemed fine, obtained water without having the deep growing tap roots of the older trees. Was it by root grafts, she wonders? Then, as she proceeds, she again examines the soil filled with fungal strands and sees a coral fungus growing out of a bed of lichens and wonders if these fungal threads might not be providing water and nutrients to the trees. Her comment is that in forestry school, she was told that trees only compete with one another and therefore why a logging company wanted fast growing trees spaced well apart and in rows. She gets to the rodeo but the bull throws Kelly with the result his right arm is pulled out of its socket and has to be reinserted, a painful process.

Again, this melding of personal family recollections together with her forestry observations and experiences is a characteristic feature of the book. As a graduate forester, she describes her first contract project with the British Columbia Forest Service to conduct an experiment of the effects of a herbicide on the survival and growth of planted spruce seedlings and naturally seeded spruce on the site of a several years older cutover of a three hundred yearold forest. At her Mother's suggestion, she employs her older sister Robyn to assist her. Ostensibly, the experiment is to determine if the result of the herbicide allows the planted seedlings to grow faster and achieve a "free-togrow" status according to a provincial policy of which she is disparaging but does not explain. The term "free-togrow is used to assess whether a naturally or artificially regenerated stand of 
young trees of a designated species has reached a state of growth, usually a specific height and density, such that it can be included in the overall forest inventory and therefore be a part of the assessment of future timber yield. The precise level used for determination will depend on the tree species, site condition and forest management objectives. Needless to say, Simard's response to the killing of vegetation by the herbicide is emotive and she decides the reason for the ailing spruce seedlings was that they "couldn't connect with the soil".

She is successful in obtaining a grant to study possible connections between conifer seedlings and mycorrhizal fungi. The experiment is to include three conifers-larch, cedar and fir in different mixtures of birch. Underlying this is her preconception that "trees and plants could somehow perceive how close their neighbours were and even who their neighbours were". The selection of a suitable large area for the experiment and its establishment proved beset with problems. Part of the chosen flat clearcut area also was being used by a rancher to graze his cows, illegally, and because of the presence of a root disease (Armillaria) infecting existing pines, she had to have twenty thousand stumps removed as well as the infected pines, resulting in the loss of much of the existing forest floor and exposing the mineral soil beneath. After many failures of all species of the experimentally planted seedlings, she decides to collect soil from an adjacent forest of fir and birch trees and add this to a third of each planting hole. A year later these trees have survived while the remainder have died. After completing her Master's degree at Oregon State University, she obtained a position as a silviculture research forester with the British Columbia Forest Service.

Simard then conducts an experiment to determine the effects of alder competing with lodgepole pine seedlings, particularly in terms of water supply. She recounts the frustration of having prisoners used to cut the alders in a statistical plot layout; after two hours the prisoners stopped work and were removed (she does not explain how the prisoners came to be used in the first place). Fortunately, she again employs her sister Robyn to help and then later, other family members, including her brother Kelly, mother and father, assist in the various activities plus Don, a research assistant from Oregon State University whom she had met while there as a student.

Anyone who has undertaken field experiments in forests based on sound but often complicated statistical designs is inevitably confronted with the inherent variability of the forest, often the difficulty of access to the chosen location especially in using elaborate and sophisticated scientific equipment such neutron probes, gas chromatographs, and the weather-in summer, the inevitable annoying plague of insects such as blackflies, deer flies and mosquitoes. The account of the setting up of the field trial, which formed a basis for her Ph. D studies, clearly documents such difficulties. From these experiences and her general observations she, "sensed that trees and plants could somehow perceive how close their neighbours were-even who their neighbours were".

Her description of attending as a speaker to describe the results of her experiment with alders and pines at a meeting in Williams Lake, at which a representative of a herbicide company was also a speaker, is illustrative. It shows her negative view of provincial forest policy makers and the use of herbicides to foster conifer regeneration to achieve free-to-grow status, and her sense of an underlying misogynist attitude among the prevailing males at the meeting. She portrays the typical negative responses that arise when the results of a specific experiment challenge a broader policy that deals with forest vegetation management. Are the results of the trial unique to that particular set of conditions? Then discussions at the meeting drift into situations and species that deflect from the specific topic she presented. One of the species mentioned is birch which is one of the species in her upcoming doctoral thesis and the basis for her paper published in Nature. ${ }^{6}$ After the session, she retreats to solace herself at a local pub attended by her brother Kelly. It is here that she gets into an argument with him and he displays his views on women-"The cows are the centre of the herd. Their

${ }^{6}$ Simard, S.W., Perry, D.A., Jones, M.D. et al. 1997 Nature 388: 579-82 only job is to feed the calves", he explains. This and the effects of alcohol were too much and resulted in what she calls a "cold war with her brother as well as the policy guys" and leads to the crux of her position about the management of forests, crops in agriculture, and stock animals on farms. She states that it is the theory of dominance put into practice by silvicultural and agricultural practices that promote the growth of the prized individuals; the beneficiaries are the pesticide, fertilizer and genetics programs that promote high yield crops instead of diverse fields.

During the completion of her doctoral work at Oregon State University, she receives a phone call that her brother Kelly has been killed at his farm, crushed between the barn door and his truck. Flying back to Kamloops for the funeral, she realizes that she and her brother will never be reconciled. She says it was because of Kelly who spurred her to publish her research in Nature. She then does what many foresters who have either managed forests or conducted experiments in the field do-she returns later to examine the areas of earlier experiments and describes one where she planted fir seedlings under a dense forest canopy of old Douglas-fir and birch trees, and one half of the seedlings were planted in plots in which their root systems were isolated by metal cylinders from the surrounding soil and others were not. The seedlings isolated by the metal rings were dead, whereas the others were alive and had mycorrhizal roots. In the trenching experiment, she describes the large difference between the two in degree of mycorrhizal occurrencelarger and with more types of fungi in the untrenched seedlings than the trenched. The fact that the seedlings used were one-year-old and in two locations they were lost to deer browsing so that she had to replant those lost and that the final measurements were taken after two growing seasons except for the replanted plots which only had one season raises questions. She describes most of her experiments in some depth, especially about their establishment and the types of measurements used and for each chapter in her book a list of references, some of which pertain to the experiments she describes, for example, the trenching experiment was published 
in 1997. ${ }^{7}$ It is only there that the reader finds out about the limited growth periods due to deer browsing. When she returns to these plots, apparently in the winter, a year after the end of the trial, she notes a group of untrenched seedlings with green leaders about one centimeter in length, and digging through the snow traces the mycelium of one seedling root to a large Douglasfir a few metres away, while another mycorrhizal root attached to a different fungus she traces to an old birch. Again she has confirmed that a host species can be connected by mycorrhizal fungi to two different plant species, one the same as the host, Douglas-fir, and the other a birch.

For each of the chapters Simard lists a series of references almost entirely of scientific papers, but unfortunately for a professional forester or scientist she does not cite them appropriately in her text. While this may be of no consequence to the general reader, it is at times disconcerting as evidenced in the discussion about the growing periods in the trenching experiment. Another example is her description of the mapping of the network of fungal mycelia in $30 \mathrm{~m}$ x $30 \mathrm{~m}$ plots in a multiaged Douglas-fir stand, (Beiler et al. ${ }^{8}$ ). The placing of one of the mapping figures from that paper in her book would have been far more interesting, even to a general reader, than some of the other photos in the book such as those of bears or tree bark. She has confirmed what former investigators have found, namely that a mycorrhizal fungus can connect trees of different ages of the same species and indeed with other tree species, and that the fungal connecting networks can be a pathway for the movement of carbohydrates, especially from the host tree to the fungus, but also a pathway for nutrients. She then extrapolates this to the concept of the "Mother Tree", trees

\footnotetext{
${ }^{7}$ Simard, S.W., Perry, D.A., Smith, J.E., Molina, R. 1997. Effects of soil trenching on occurrence of ectomycorrhizas on Pseudotsuga menziesii seedlings grown in a natural forest of Pseudotsuga menziesii and Betula papyrifera. New Phytologist 136: 327-340

${ }^{8}$ Beiler,K. J., Durall, D.M.,Simard, S.W. et al. 2010. Mapping the Wood-wide Web: Mycorrhizal networks link multiple Douglas-Fir cohorts. New Phytologist 185: 543-53
}

which connect the forest, leading her to postulate that, beyond the movements of carbohydrates and nutrients, the mycorrhizal network also functions in transmitting signals between trees: "Could information be transmitted across synapses in mycorrhizal networks, the same way it happens in our brains?" This leads her to another question about whether one species such as Douglas-fir can warn another species, for example, ponderosa pine, about insect infestations. She then recounts the experiment she and a visiting Chinese scientist set up to answer the question (Song et al. ${ }^{9}$ ). Earlier, referring to bark beetle attacks on lodgepole pine, she suggests that the beetles would start infesting "the jack-pine hybrids across the boreal forest of Canada". This statement reflects her limited knowledge of the occurrence of lodgepole-jack pine hybrids to western Canada, such as part of Alberta. The concept of the "Mother Tree" is also based on its ability to recognize, via mycorrhizal fungi connections, that in the transfer of carbohydrates there is a recognition of kinship between the "Mother Tree" and seedlings from it and those not genetically connected (Pickles et al. ${ }^{10}$ ).

Her personal bout with cancer and description of the treatments involved lead her to the metaphor of her as the Mother Tree in relation to her two daughters. Thus throughout the book her personal and family lives are interwoven with her experimental and professional activities. Indeed, toward the end of the book she describes taking her older daughter to an area showing the results of long-term mining for base metals and its effects on the forest. This was followed by a trip to Haida Gwai with a graduate student to examine the possible effects of nitrogen derived from salmon caught by bears, then finally a brief word about an extensive

9ong, Y.Y., Simard, S.W., Carroll, A. 2015. Defoliation of interior Douglas-fir elicits carbon transfer and defense signaling to ponderosa pine neighbors through ectomycorrhizal networks. Scientific Reports 5: 8495

${ }^{10}$ Pickles, B.J., Wilhelm, R., Asay, A. K., et al. 2017. Transfer of $13 \mathrm{C}$ between paired Douglas-fir seedlings reveals plant kinship effects and uptake of exudates by ectomycorrhizas. New Phytologist 214: 400-411
Mother Tree project in British Columbia and its implications in future forest management. It is here that her apparent blind spot in her forestry career is apparent. Nowhere does she recognize the many hundreds of thousands if not millions of hectares in Canada and elsewhere in the world, particularly in the United Kingdom, Scandinavia and Europe where her very bêtes noirs of plantations, the concept of free-to-grow and deliberate forest management planning to grow trees for harvesting has successfully occurred without significant ecological damage and sometimes with enhancement. What she ignores is the basic forest management planning concept of designing and managing forests in recognition of the values that society puts on them, and that some areas are better suited to focusing on timber harvests while others can be managed for arrays of other values which may or may not include some limited form of harvesting. What Simard has done is bring the important role of mycorrhizas and their important role to forest trees and forests generally to a wider public. The danger is that the public may consider that the "Mother Tree" concept is the only guide to managing forests.

Reviewed by

Ken Armson O.C., R.P.F. (ret.) 


\section{From Backwoods to Boardrooms: The Rise of Institutional Investment in Timberland}

Daowei Zhang. 2021. ISBN 978-08707-1142-8. Oregon State University Press, Corvallis, Oregon. US \$ $45.00+$ shipping. Contact: htpps://osupress.oregonstate.edu

The largest and most significant change in forestland in the last 40 years has been the shift from industrial to institutional ownership. Professor Zhang traces the detail of this transfer in his new book, From Backwoods to Boardrooms: The Rise of Institutional Investment in Timberland. Binkley's engaging short foreword to Zhang's book reminds us that the institutional ownership of forestland began in the year 1288 with a gift from the king to Sweden's church. In US history, it began with a much more recent loan from Travelers Insurance to the St. Regis Paper Company in 1952. Most of us are more aware, however, of the large shifts in ownership since approximately 1990. Industrial ownerships accounted for $14 \%$ of US forestland and almost 30 $\%$ of US timber supply in the 1980s. By 2021, the forest industry's land holdings have almost disappeared, while pension funds, insurance companies, banks, foundations, endowments and highnet-worth individuals, now organized as timberland investment management organizations (TIMOs) and real estate investment trusts (REITs), non-existent in forestry before the 1980s, now control more than 50 million acres of US forestland. Zhang explains the history and the economics of this transition in eight chapters: 1) the documented and enumerated pattern of industrial ownership in the 20th century, 2) the fundamental economic valuation of timberland, 3) the emergence of TIMOs, 4) the story of the buyers and sellers of the 1980s and 1990s, 5) the growth of TIMOs and their role in forest management, 6) timberland REITS, 7) the growing global experience, and 8) future prospects. The history is built on Zhang's 28 years of experience and interviews, seemingly hundreds of hours of them, with many of the pioneers and principal actors in the process; brokers, investment consultants, financial managers and bankers. Each share their own perspectives on the reasons for corporate financial decisions. The "stories" in this history go beyond chronology and sometimes become a lot for the reader to work through-but the detailed personal insight is worth it. The economics builds from formal modelling of the initial justification for industrial ownership, of timberland valuation, and the Cap-M formulation of the risk-return tradeoff. The first is new and useful. The second and third are well-known but nowhere to my knowledge as clearly stated and accompanied with real world detailed empirical evidence. In fact, I'd say that these are better than those in any forest economics textbook of my familiarity. All foresters, whether practicing in the field, managing from corporate industrial or timberland offices, or observing from positions in research or academe, are aware of this important transition in forestland ownership. The details and also the changes in expectations that come with it have been beyond most of us. Zhang has made them clear for all of us. I recommend Zhang's book for anyone

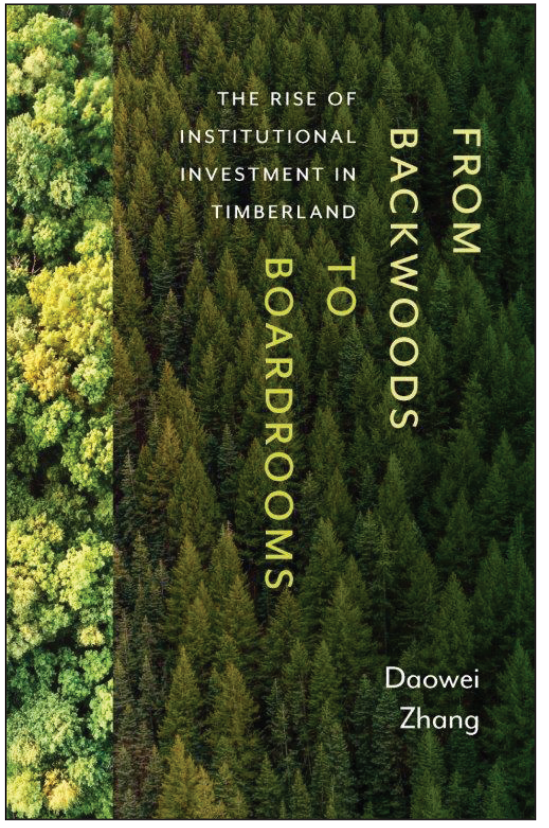

interested in understanding these changes. From Backwoods to Boardrooms is remarkable for its detail and for the thoroughness of both its historical and economic components. Zhang has told his story well. I'd add that this latest effort of Professor Zhang confirms his position among the foremost of this generation of social scientists working in forestry.

Reviewed by William F. Hyde, retired,wfhyde1@gmail.com, Grand Junction, Colorado, USA 81507 